\title{
PENURUNAN NYERI SAAT DISMENORE DENGAN SENAM YOGA DAN TEKNIK DISTRAKSI (MUSIK KLASIK MOZART)
}

\author{
Remilda Armika Vianti*, Diyah Ari S. \\ Universitas Pekalongan Program Studi Ilmu Keperawatan \\ J1. Sriwijaya No. 3 Pekalongan Telp. (0285) 421096 \\ Korespondensi: vivi.unikal@gmail.com
}

\begin{abstract}
Women have experienced dysmenorrhea as much as $90 \%$. In general, 50-60\% of women require analgesic drugs to overcome the problem of dysmenorrhea. The prevalence of menstrual pain in women was $84.1 \%$, of which $43.1 \%$ of pain occurred during each menstrual period or every month, and $41 \%$ of pain was felt for several menstrual periods or did not occur every month. The prevalence of dysmenorrhea in asia is $74.5 \%$ of girls who have reached menarche have dysmenorrhea; $51.7 \%$ affect their concentration in the classroom; $50.2 \%$ of their social activities are limited; $21.5 \%$ caused them to lose school; and $12.0 \%$ poor school performance. In Indonesia the figure is estimated 55\% of women of reproductive age who are tormented by pain during menstruation. The incidence rate (prevalence) of menstrual pain is around 45-95\% among women of reproductive age. The purpose of this study was to find out how effective yoga exercises and distraction techniques (listening to classical mozart music) in reducing pain during menstruation (dysmenorrhea). The method of this research is Quasi Experiment Design method with Pre test design and Post test Design. Where in this design there are 2 group (two group) experiment. The sample was 28 respondents for each group using random sampling method. Technique of collecting data with pain scale observation scale using scale scale with score 1-10 with criterion of mild pain, moderate pain, severe pain. However, in this study using 2 categories, namely mild pain and moderate pain. Analysis of the results of the study using Mann-Whitney test because the data is not normally distributed. Mann-Whitney test results in this study obtained p-value value 0.024 . So it can be concluded: Yoga gymnastics is more effective than distraction technique (listening to classical mozart music) in reducing pain during menstruation (dysmenorrhea) in high school students Pekalongan.
\end{abstract}

Keyword: Dismenore, yoga, distraction

\begin{abstract}
ABSTRAK
Wanita pernah mengalami dismenore sebanyak 90\%. Pada umumnya 50-60\% wanita diantaranya memerlukan obat analgesik untuk mengatasi masalah dismenore. Prevalensi nyeri haid pada perempuan sebanyak $84,1 \%$, dimana $43,1 \%$ nyeri yang terjadi selama setiap periode menstruasi atau setiap bulan, dan $41 \%$ nyeri di rasakan terjadi selama beberapa periode menstruasi atau tidak terjadi setiap bulannya. Prevalensi dismenore di asia sebesar $74,5 \%$ dari gadis-gadis yang telah mencapai menarche memiliki dismenore; 51,7\% mempengaruhi konsentrasi mereka di kelas; 50,2\% kegiatan sosial mereka terbatas; 21,5\% menyebabkan mereka kehilangan sekolah; dan 12,0\% prestasi sekolah buruk. Di Indonesia angkanya diperkirakan 55\% perempuan usia produktif yang tersiksa oleh nyeri selama menstruasi. Angka kejadian (prevalensi) nyeri menstruasi berkisar 45-95\% di kalangan wanita usia produktif. Tujuan dari penelitian ini adalah untuk mengetahui seberapa efektif senam yoga dan teknik distraksi (mendengarkan musik klasik mozart) dalam menurunkan nyeri saat menstruasi (dismenore). Metode penelitian ini adalah metode Eksperimen Semu (Quasi Experiment Design) dengan rancangan Pre test dan Post test Design. Dimana pada desain ini terdapat 2 kelompok (two group) eksperimen. Sampel penelitian sebanyak 28 responden untuk masing-masing kelompok dengan menggunakan metode random sampling. Teknik pengumpulan data dengan lembar observasi skala nyeri dengan menggunakan skala angka dengan skor 1-10 dengan kriteria nyeri ringan, nyeri sedang, nyeri berat. Akan tetapi pada penelitian ini menggunakan 2 kategori, yaitu nyeri ringan dan nyeri sedang. Analisis hasil penelitian menggunakan uji Mann-whitney karena data berdistribusi tidak normal. Hasil uji Mann-whitney pada penelitian ini didapatkan nilai p-value 0,024. Maka dapat disimpulkan: Senam yoga lebih efektif daripada teknik distraksi (mendengarkan musik klasik mozart) dalam menurunkan nyeri saat menstruasi (dismenore) pada Siswi SMA N 4 Pekalongan.
\end{abstract}

Kata Kunci : Nyeri menstruasi, yoga, distraksi 


\section{PENDAhULUAN}

Wanita pernah mengalami dismenore sebanyak 90\%. Masalah ini setidaknya mengganggu $50 \%$ wanita masa reproduksi dan $60-85 \%$ pada usia remaja, yang mengakibatkan banyaknya absensi pada sekolah maupun kantor. Pada umumnya 50-60\% wanita diantaranya memerlukan obat analgesik untuk mengatasi masalah dismenore. (Annathayakheisa, 2009).

Prevalensi nyeri haid yang dilaporkan sebanyak $84,1 \%$ perempuan, dimana $43,1 \%$ melaporkan bahwa nyeri yang di rasakan terjadi selama setiap periode menstruasi atau setiap bulan, dan $41 \%$ melaporkan sakit yang di rasakan terjadi selama beberapa periode menstruasi atau tidak terjadi setiap bulannya (Grandi et al, 2012).

Prevalensi dismenore di asia sebesar 74,5\% dari gadis-gadis yang telah mencapai menarche memiliki dismenore; 51,7\% dari gadis-gadis ini melaporkan bahwa itu mempengaruhi konsentrasi mereka di kelas; 50,2\% yang membatasi kegiatan sosial mereka; 21,5\% yang menyebabkan mereka kehilangan sekolah; dan 12,0\% yang disebabkan prestasi sekolah yang buruk (Khoo, E. M. et al, 2010). Di Indonesia angkanya diperkirakan 55\% perempuan usia produktif yang tersiksa oleh nyeri selama menstruasi. Angka kejadian (prevalensi) nyeri menstruasi berkisar $45-95 \%$ di kalangan wanita usia produktif. (Marlinda, et al. 2013).

Menurut Siahaan, K. et al. (2012) dengan judul Penurunan Tingkat Dismenore Pada Mahasiswa Fakultas Ilmu Keperawatan UNPAD Dengan Menggunakan Yoga didapatkan hasil bahwa yoga dapat menurunkan dismenore dengan p-value $=0.000$. berdasarkan penelitian maka yoga dapat dijadikan sebagai salah satu alternatif intervensi untuk dismenore.

Penelitian lain juga dilakukan oleh Sari, P. (2012) dengan judul Perbedaan Terapi Musik Klasik Mozart Dengan Terapi Musik Kesukaan Terhadap Intensitas Nyeri Haid Pada Remaja Putri Di SMA Negeri 5 Denpasar di dapatkan hasil bahwa ada perubahan dalam intensitas nyeri haid setelah diberikan musik klasik Mozart dan terapi musik kesukaan.

Berdasarkan penelitian-penelitian tersebut yang sudah dilakukan jelas terlihat bahwa senam yoga dan teknik distraksi (mendengarkan musik klasik mozart) berpengaruh dalam penurunan nyeri dismenore. Akan tetapi yang menjadi perhatian penulis adalah Seberapa efektifkah antara senam yoga dan teknik distraksi (mendengarkan musik klasik mozart) dalam menurunkan nyeri saat menstruasi (dismenore).

Berdasarkan hasil studi pendahuluan didapatkan hasil 9 dari 10 siswi selalu mengalami nyeri saat menstruasi. Dari sebagian siswi tersebut mengatasi dismenore dengan relaksasi (nafas dalam), berdasarkan studi pendahuluan dengan menggunakan checklist juga didapatkan data bahwa siswi tersebut belum mengetahui tentang senam yoga dan teknik distraksi (mendengarkan musik klasik mozart) dalam mengatasi nyeri haid. Pada saat melakukan study pendahuluan peneliti juga mencari data di UKS masing-masing sekolah, namun data yang didapat dari UKS sedikit, karena kebanyakan dari siswi tersebut tidak sampai masuk UKS. Sehingga peneliti mengambil data melalui checklist yang dibagikan kepada siswi.

\subsection{Rumusan Masalah}

Berdasarkan uraian latar belakang di atas, maka dapat dirumuskan permasalahan sebagai berikut : 
1. Seberapa efektifkah senam yoga dalam menurunkan nyeri saat menstruasi (dismenore).

2. Seberapa efektifkah teknik distraksi (mendengarkan musik klasik mozart) terhadap penurunan nyeri saat menstruasi (dismenore).

\subsection{Hipotesis Penelitian}

Senam yoga dan distraksi (mendengarkan music klasik Mozart) efektif terhadap penurunan nyeri saat menstruasi (dismenore).

\section{TINJAUAN PUSTAKA}

\subsection{Dismenore}

Menstruasi adalah peristiwa perdarahan secara periodik siklik (bulanan) dari rahim yang disertai pelepasan selaput lendir rahim (endometrium) melalui vagina pada wanita yang sudah dewasa secara seksual. (Kusmiran, 2011). Umumnya, remaja yang mengalami menarche adalah pada usia 12 sampai 16 tahun. Dan periode ini akan mengubah perilaku dari beberapa aspek, misalnya aspek psikologi dal lainnya. Pada wanita biasanya pertama kali menarche pada usia 12-16 tahun. Siklus menstruasi normal terjadi setiap 22-35 hari, dengan lamanya menstruasi selama 2-7 hari. (Kusmiran, 2011: 19).

Menstruasi adalah pelepasan dinding rahim (endometrium) yang disertai dengan perdarahan dan terjadi setiap bulannya kecuali pada saat kehamilan. Menstruasi yang terjadi terus menerus setiap bulannya disebut sebagai siklus menstruasi. Menstruasi biasanya terjadi pada usia 11 tahun dan berlangsung hingga menopause (biasanya terjadi sekitar usia 45-55 tahun). Normalnya, menstruasi berlangsung selama 3-7 hari. (Aisyah, 2010).

Siklus menstruasi bervariasi pada tiap wanita dan hampir $90 \%$ wanita memiliki siklus $25-35$ hari dan hanya $10-15 \%$ yang memiliki panjang siklus 28 hari, namun beberapa wanita memiliki siklus yang tidak teratur dan hal ini bisa menjadi indikasi adanya masalah kesuburan. (Aisyah, 2010).

Pada saat menstruasi, wanita kadang mengalami nyeri. Sifat dan tngkat rasa nyeri bervariasi, mulai dari yang ringan hingga berat. Kondisi tersebut dismenore, yaitu keadaan nyeri yang hebat dan dapat mengganggu aktivitas sehari-hari. Dysmenore merupakan suatu fenomena yang simptomatik meliputi nyeri abdomen, kram, dan sakit punggung. Gejala gastrointestinal seperti mual dan diare dapat terjadi sebagai gejala dari menstruasi. (Kusmiran, 2011: 112).

Dismenore adalah nyeri perut yang berasal dari kram rahim dan terjadi selama menstruasi. (Aisyah, 2010 ). Menurut Simanjuntak pada tahun (1997) dismenore adalah nyeri pada daerah panggul akibat menstruasi dan produksi zat prostaglandin. Sering kali dimulai setelah mengalami haid yang pertama (menarche). Nyeri berkurang setelah menstruasi, namun pada beberapa wanita nyeri bisa terus dialami selama periode menstruasi. Nyeri menstruasi cenderung lebih sering terjadi pada gadis remaja yang mengalami kegelisahan, dan kecemasa. Jika tidak segera ditangani akan mengganggu aktivitas para wanita. (Kusmiran, 2011).

\subsection{Senam Yoga}

Yoga berasal dari bahasa sansekerta yang berarti union atau penyatuan. Penyatuan yang sejati adalah penyatuan dengan sang illahi. Selama beryoga kita 
merasakan penyatuan dalam tubuh kita antara pikiran, napas, dan jiwa. Menurut kitab kuno, yoga adalah ilmu yang membuat kita dapat menjalani hidup yang lebih harmoni, seimbang melalui pengendalian pikiran dan tubuh. Jadi yoga adalah filosofi hidup kita yang setiap gerakannya mencerminkan filosofi hidup. (Rohimawati, R. 2008).

Dalam bahasa sanskerta, yoga berarti menyelaraskan tubuh, roh, dan jiwa. Latihan-latihan yoga bekerja pada segala macam sistem tubuh dan memberikan sejumlah manfaat untuk para wanita, termasuk membantu meredakan ketidaknyamanan yang ditimbulkan oleh menstruasi, kehamilan, dan menopause. (Kanisius, 2009).

\subsubsection{Cara-cara Melakukan Yoga Sikap Kobra}

Asana ini bermanfaat bagi tubuh wanita karena mengatur kelenjar anak ginjal (kelenjar suprarenal), memperkuat punggung, meningkatkan kelenturan tulang punggung, dan membantu menguatkan otot-otot perut. Selain itu juga meningkatkan energi dan kepercayaan diri anda. Asana juga membantu mengatur periode menstruasi dan meredakan ketegangan.

a) Berbaringlah telungkup, kedua kaki rapat, dan dahi menempel di lantai ditumpu oleh telapak tangan yang ditekankan pada lantai. Kaki sebaiknya lurus, bagian depan kaki menempel di lantai. Tekankan pantat untuk membantu bergerak ke posisis berikutnya dan letakkan siku, lengan bawah, dan telapak tangan di lantai. Siku harus sama tinggi dengan bahu dan kepala ditekankan ke lantai.

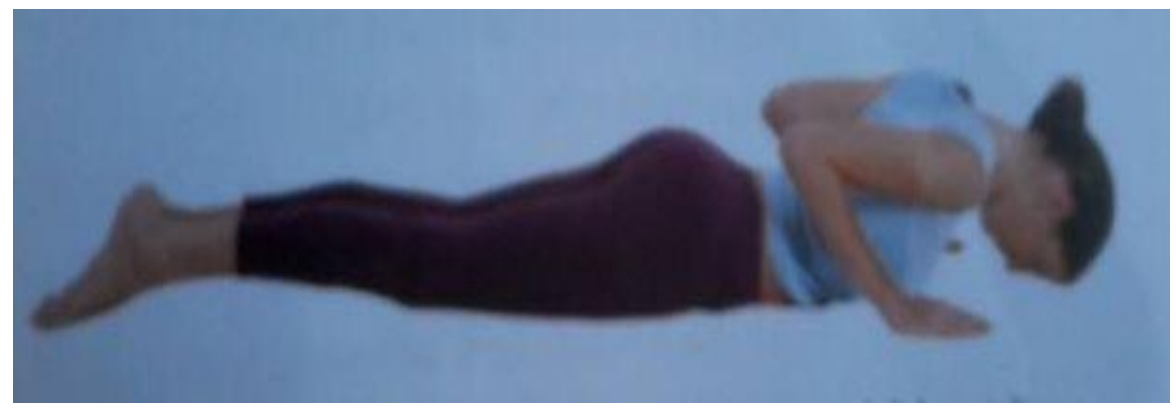

Gambar 1 Cara Melakukan Yoga Sikap Kobra

b) Angkat dada, sambil kontraksikan pantat sehingga tidak mengganggu leher. Ketika mengangkat dada, sekaligus luruskan lengan. Jika gerakan ini menyebabkan ketidaknyamanan, jangan mengejan dan tetaplah melihat ke bawah. Bernapaslah secara normal. Untuk melepaskan, turunkan tubuh pelan-pelan, letakkan ke lantai secara berurutan: perut, dada, dan yang terakhir dagu, selalu julurkan ke depan. Kemudian, gerakkan dagu ke bawah dan bertumpulah di lantai dengan salah satu pipi.

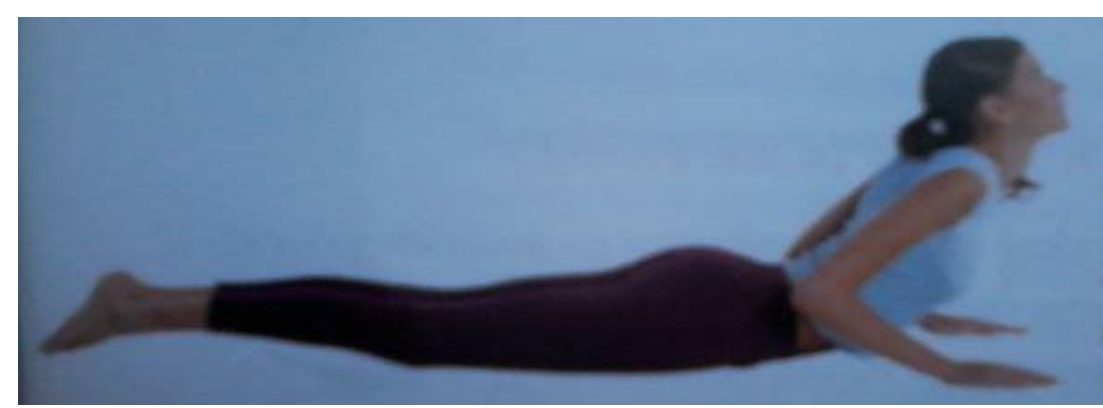

Gambar 2 Cara Melakukan Yoga Sikap Kobra 


\subsubsection{Cara-cara Melakukan Yoga Sikap Sikap Kucing (cat pose)}

Asana ini ideal untuk membantu meredakan nyeri perut selama masa sindrom premenstruasi, periode menstruasi, dan juga ideal untuk meredakan nyeri selama masa kehamilan.

a) Mulailah pada kedua tangan dan lutut, dengan lutut terpisah penuh. Gerakkan panggul ke belakang, tekuk lengan dan letakkan dahi diatasnya, biarkan pantat menunjuk ke atas. Bernapaslah pelan-pelan dan dalam, relaksasikan seluruh tubuh.

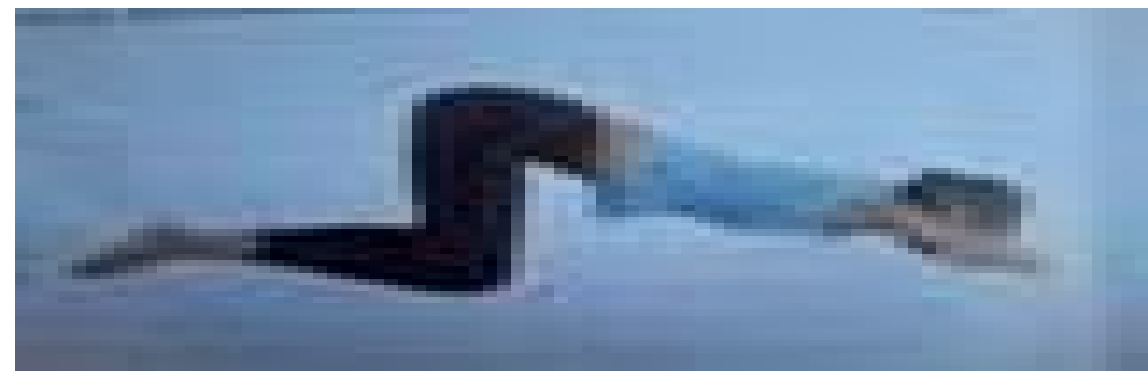

Gambar 3 Cara Melakukan Yoga Sikap Kucing

b) Mulailah dari posisi sebelumnya, rapatkan pergelangan kaki dan duduklah diatasnya dengan siku ditekankan ke lantai . Pertahankan asana ini selama merasa nyaman, bernapaslah secara normal dan dalam, cari relaksasi maksimum. (Kanisius, 2009).

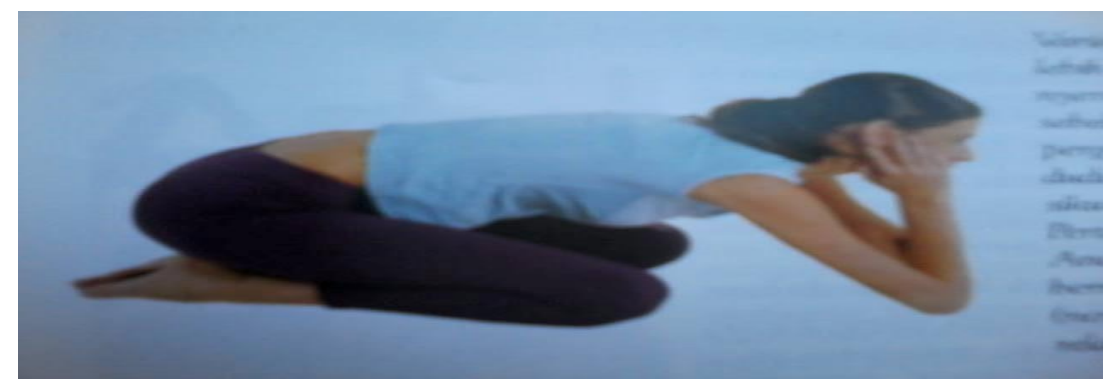

Gambar 4 Cara Melakukan Yoga Sikap Kucing

\subsection{Distraksi}

Distraksi adalah mengalihkan perhatian klien dari nyeri. (Asmadi, 2008: 149). Terapi musik adalah disiplin ilmu rasional yang memberi nilai tambah pada musik sebagai dimensi baru secara bersama dapat mempersatukan seni ilmu pengetahuan dan emosi (perasaan cinta, kasih sayang, dan lain sebagainya). Musik telah digunakan sebagai salah satu aktivitas dalam proses pengobatan berbagai penyakit fisik maupun mental. (Musbikin, I. 2009: 255).

Musik adalah bunyi yang diterima oleh individu yang berbeda-beda berdasarkan sejarah, lokasi, budaya dan selera seseorang. Definisi sejati tentang musik juga bermacam-macam, diantaranya:

a) Bunyi atau kesan terhadap sesuatu yang ditangkap oleh indra pendengar.

b) Suatu karya seni dengan segenap unsur pokok dan pendukungnya.

c) Segala bunyi yang dihasilkan secara sengaja oleh seseorang atau kumpulan dan disajikan sebagai musik. (Rasyid, F. 2010: 13). 
Musik merupakan sebuah rangsangan audio proporsional yang terdiri dari melodi, ritme, harmoni, timbre, bentuk, dan gaya. Musik memiliki kekuatan untuk mengobati penyakit dan ketidakmampuan yang dialami oleh tiap orang. Ketika diaplikasikan menjadi sebuah terapi, musik dapat meningkatkan, memulihkan, dan memelihara kesehatan fisik mental, emosional, sosial, dan spiritual seseorang. Hal ini dikarenakan musik memiliki beberapa kelebihan, seperti bersifat universal, memberikan rasa nyaman dan menyenangkan, dan berstruktur. (Musbikin, I. 2009: 243-244).

Terapi musik merupakan sebuah pekerjaan yang menggunakan musik dan aktivitas musik untuk mmengatasi kekurangan dalam aspek fisik, emosi, kognitif adan sosial pada anak-anak serta orang dewasa yang mengalami gangguan atau penyakit tertentu. (Djohan, 2006).

\subsubsection{Manfaat Mendengarkan Musik}

Ternyata musik bisa mempengaruhi sistem limbik dan saraf otonom. Musik bisa memperbaiki suasana hati (mood), baik itu menciptakan suasana tenang, rileks, aman maupun menyenangkan sehingga membuat suasana menjadi nyaman. Manfaat mendengarkan musik: Salah satu manfaat musik dalam membuat pikiran lebih rileks adalah kemampuannya mengaktifkan selsel dalam diri seseorang sehingga kekebalan tubuhnya naik. Musik juga bisa meningkatkan produksi hormon serotonin. Serotonin merupakan zat kimia yang mentransmisikan impuls saraf diseluruh ruang antara sel-sel saraf maupun neuron. Perubahan dalam tingkat serotonin dalam otak mempengaruhi suasana hati menjadi lebih tenang dan rileks. (Sumaryati \& Hastomi, 2012: 26).

\subsubsection{Unsur-unsur Musik}

a. Nada adalah bunyi yang beraturan atau bunyi yang memiliki frekuensi tunggal tertentu.

b. Ritme atau irama adalah variasi horizontal dan aksen dari suatu suara teratur.

c. Melodi adalah serangkaian nada dalam waktu tertentu. Rangkaian tersebut dapat dibunyikan sendiri tanpa iringan.

d. Harmoni adalah dua nada atau lebih dengan tinggi nada yang berbeda-beda ketika dibunyikan bersamaan, juga dapat terjadi bila nada-nada tersebut dibunyikan secara berurutan. Harmoni yang terdiri dari tiga atau lebih nada yang dibunyikan bersamaan biasanya disebut akor.

e. Notasi musik adalah sistem penulisan karya musik. Dalam notasi musik, nada dilambangkan oleh not. Tulisan musik biasanya disebut partitur. Notasi standar saat ini adalah notasi balok yang didasarkan pada paranada dengan lambang untuk tiap nada menunjukkan durasi, dan ketinggian nada tersebut. Tinggi nada digambarkan secra vertical sedangkan waktu (ritme) digambarkan secara horisontal. Durasi nada ditunjukkan dalam ketukan. Terdapat pula bentuk notasi lain, misalnya notasi, angka yang juga digunakan di Negara-negara Asia, termasuk Indonesia.

f. Notasi Gregorian, merupakan awal dari notasi balok. (Rasyid, F. 2010: 1517). 


\subsection{Musik Klasik}

Musik klasik adalah komposisi musik yang lahir dari budaya Eropa sekitar tahun 1750-1825. Ada pula pengertian lain dari musik klasik, yaitu semua musik dengan keindahan intelektual yang tinggi dari semua zaman, baik itu berupa simponi Mozart, Kantata Bach, atau karya-karya abad 20. Istilah keindahan intelektual itu sendiri memiliki pengertian yang relatif bagi setiap orang. (Musbikin, I. 2009: 150151).

Musik klasik merupakan istilah luas yang biasanya mengacu pada musik yang dibuat atau berakar dari tradisi kesenian barat, musik Kristen, dan musik orchestra, mencakup periode abad ke-19 hingga abad ke-21. (Rasyid, F. 2010: 53).

Manfaat musik klasik adalah sebagai berikut :

a. Untuk kecerdasan otak.

b. Dapat memberi semangat pada jiwa yang lelah, resah, dan lesu.

c. Memberikan rasa santai dan nyaman atau penyegaran pada pendengarannya.

d. Dapat menyembuhkan depresi.

e. Membantu menenangkan, dan merangsang bagian otak yang terkait ke aktivitas emosi, dan tidur.

f. Membantu menurunkan tingkat stres dan gelisah.

g. Dapat menyembuhkan sakit dalam tubuh dan membantu otot menjadi rileks. (Rasyid, F. 2010: 71-72).

\section{METODE PENELITIAN}

Metode Eksperimen Semu (Quasi Experiment Design) dengan rancangan Pretest and Posttest Design. Dimana pada desain ini terdapat 2 kelompok (two group) eksperimen dengan perlakuan berupa:

1. Pembagian lembar observasi skala nyeri sebelum dan sesudah senam yoga.

2. Pembagian lembar observasi skala nyeri sebelum dan sesudah teknik distraksi (mendengarkan musik klasik mozart).

\section{Kelompok \\ Eksperimen}

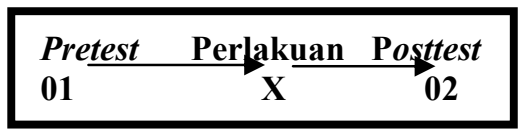

01 : Pretest, mengukur skala nyeri sebelum diberi perlakuan senam yoga.

01 : Pretest, mengukur skala nyeri sebelum diberi perlakuan teknik distraksi (mendengarkan musik klasik mozart).

$\mathbf{X}$ : Memberikan perlakuan senam yoga.

X : Memberikan perlakuan teknik distraksi (mendengarkan musik klasik mozart).

02 : Posttest, mengukur skala nyeri sesudah diberi perlakuan senam yoga.

02 : Posttest, mengukur skala nyeri sesudah diberi perlakuan teknik distraksi (mendengarkan musik klasik mozart).

\subsection{Uji Analisa Data}

\subsubsection{Analisis Univariat}

Analisis ini dilakukan untuk mendiskripsikan masing-masing variabel yang diteliti. Peneliti mendiskripsikan karakteristik atau data demografi subyek penelitian. Karakteristik responden yang akan dilakukan analisis univariat meliputi:

a) Presentase dan rata-rata skala nyeri sebelum dan sesudah senam yoga. 
b) Presentase dan rata-rata skala nyeri sebelum dan sesudah teknik distraksi (menndengarkan musik klasik mozart).

Penyajian data masing-masing variabel dalam bentuk tabel karakteristik responden dan tabel rata-rata skala nyeri.

\subsubsection{Analisa Bivariat}

Analisis ini dilakukan untuk membuktikan hipotesis penelitian untuk mengetahui pengaruh senam yoga dan teknik distraksi terhadap penurunan dismenore dengan cara membandingkan nilai rata-rata penurunan nyeri pada variabel bebas yaitu: pada kelompok senam yoga dan kelompok teknik distraksi (mendengarkan musik klasik mozart).

Sebelum melakukan Uji Analisis data dilakukan terlebih dahulu uji Normalitas Data untuk mengetahui tingkat kenormalan data dan setelah di uji ternyata bahwa data berdistribusi tidak normal, maka hasil analisisnya menggunakan uji nonparametrik dengan uji Mann-Whitney. Adapun hasil dari uji normalitas data adalah sebagai berikut:

Tabel 1 Uji Normalitas Data

\begin{tabular}{clc}
\hline \multirow{2}{*}{ No } & \multicolumn{1}{|c}{ Uji Normalitas } & Kolmogorov-Smirnov \\
\cline { 3 - 3 } & & Sig. \\
\hline 1. & Pre Test Yoga & 0,040 \\
2. & Pre Test Musik (Mozart) & 0,012 \\
3. & Post Test Yoga & 0,000 \\
4. & Post Test Musik (Mozart & 0,000 \\
\hline
\end{tabular}

Lillifors Significance Correction

\section{HASIL DAN PEMBAHASAN}

Pada sub bab ini disajikan hasil penelitian yang telah dilaksanakan dengan para remaja putri di SMAN 4 Kota Pekalongan.

\subsection{Analisis Univariat}

Analisis univariat dalam penelitian ini adalah penggambaran mengenai hasil test sebelum dan sesudah melakukan suatu kegiatan dalam rangka mengurangi dismenore. Terdapat 2 kegiatan yang dilakukan yakni sebagai berikut :

a. Senam Yoga

Distribusi Frekuensi Tingkat Dismenore Sebelum dan Sesudah Senam Yoga pada Siswa SMAN 4 Kota Pekalongan sebagai berikut :

Tabel 2 Hasil Pre Test Senam Yoga $(n=28)$

\begin{tabular}{ccccc}
\hline No & & Pre Test Senam Yoga & Frekuensi (f) & $\mathbf{\%}$ \\
\hline 1. & Ringan & & 9 & 32,1 \\
2. & Sedang & & 19 & 67,9 \\
\hline & & Jumlah & 28 & 100 \\
\hline
\end{tabular}

Dari tabel 2 diketahui bahwa responden yang mengalami dismenore tingkat sedang pada saat pre test sebanyak 19 orang (67,9\%). Sedangkan responden yang mengalami dismenore tingkat ringan pada saat pre test sebanyak 9 orang $(32,1 \%)$. 
Tabel 3 Hasil Post Test Senam Yoga $(\mathrm{n}=28)$

\begin{tabular}{ccccc}
\hline No & & Post Test Senam Yoga & Frekuensi (f) & $\mathbf{\%}$ \\
\hline 1. & Ringan & & 26 & 92,9 \\
2. & Sedang & Jumlah & 2 & 7,1 \\
\hline & & 28 & 100 \\
\hline
\end{tabular}

Dari tabel 3 diketahui bahwa responden yang mengalami dismenore tingkat ringan pada saat post test sebanyak 26 orang (92,9\%). Sedangkan responden yang mengalami dismenore tingkat sedang pada saat post test sebanyak 2 orang $(7,1 \%)$.

b. Teknik Distraksi (Mendengarkan Musik Klasik Mozart)

Distribusi Frekuensi Tingkat Dismenore Sebelum dan Sesudah dilakukan teknik distraksi (mendengarkan musik klasik mozart) pada Siswa SMAN 4 Kota Pekalongan sebagai berikut :

Tabel 4 Hasil Pre Test Teknik Distraksi (Mendengarkan Musik Klasik Mozart) (n=28).

\begin{tabular}{ccccc}
\hline No & \multicolumn{2}{c}{$\begin{array}{c}\text { Pre Test Teknik Distraksi } \\
\text { (Mendengarkan Musik Klasik Mozart) }\end{array}$} & Frekuensi (f) & $\%$ \\
\hline 1. & Ringan & 11 & 39,3 \\
2. & Sedang & Jumlah & 17 & 60,7 \\
\hline \multicolumn{4}{r}{} &
\end{tabular}

Dari tabel 4 diketahui bahwa responden yang mengalami dismenore tingkat sedang pada saat pre test sebanyak 17 orang (60,7\%). Sedangkan responden yang mengalami dismenore tingkat ringan pada saat pre test sebanyak 11 orang $(39,3 \%)$.

Tabel 5 Hasil Post Test Teknik Distraksi (Mendengarkan Musik Klasik Mozart) $(\mathrm{n}=28)$

\begin{tabular}{cccc}
\hline No & Post Test Kegiatan Teknik Distraksi & Frekuensi (f) & $\%$ \\
\hline 1. & Ringan & 19 & 67,9 \\
2. & Sedang & 9 & 32,1 \\
\hline & & 28 & 100 \\
\hline
\end{tabular}

Dari tabel 5 diketahui bahwa responden yang mengalami dismenore tingkat ringan pada saat post test sebanyak 19 orang (67,9\%). Sedangkan responden yang mengalami dismenore tingkat sedang pada saat post test sebanyak 9 orang $(32,1 \%)$.

Tabel 6 Rata-Rata Skala Nyeri Responden Sebelum Dan Sesudah Senam Yoga Dan Teknik Distraksi (Mozart) $(n=28)$

\begin{tabular}{lccc}
\hline \multirow{2}{*}{\multicolumn{1}{c}{ Tindakan }} & \multicolumn{2}{c}{ Mean \pm SD } & \multirow{2}{*}{ Sebelum } \\
\cline { 2 - 3 } & $4,04 \pm 1,427$ & Sesudah & \\
\hline Senam Yoga & $4,11 \pm 1,36 \pm 0,962$ & 28 \\
Teknik Distraksi (Musik) & $2,61 \pm 1,343$ & 28 \\
\hline
\end{tabular}

Dari tabel 6 dapat diketahui bahwa nilai mean sebelum Senam Yoga sebanyak 4,04 dan setelah Senam Yoga sebanyak 1,96, sedangkan nilai mean sebelum Teknik Distraksi (Mozart) sebanyak 4,11 dan setelah Teknik Distraksi (Mozart) sebanyak 2,61. 
Tabel 7 Rata-Rata Penurunan Skala Nyeri Responden Sebelum Dan Sesudah Senam Yoga Dan Teknik Distraksi (Mozart) ( $\mathrm{n}=28)$

\begin{tabular}{lll}
\hline \multicolumn{1}{c}{ Tindakan } & \multicolumn{1}{c}{ Mean \pm SD } \\
\hline Senam Yoga & $2,07 \pm 0,979$ & 28 \\
Teknik Distraksi (Musik) & $1,50 \pm 0,638$ & 28 \\
\hline
\end{tabular}

\subsection{Analisis Bivariat}

Untuk mengetahui tingkat keberhasilan pre test dan post test yang telah dilakukan maka perlu pengujian dengan uji nonparametrik dengan uji Mann-Whitney. Uji T Beda dua mean independent antara Senam Yoga dan Teknik distraksi (Mendengarkan Musik Klasik Mozart).

Tabel 8 Uji Beda Pada Penurunan Dismenore $(\mathrm{n}=28)$

\begin{tabular}{lrrl}
\hline \multicolumn{1}{c}{ Intervensi } & n & Mea $\boldsymbol{n} \pm$ SD & p-value \\
\hline Senam Yoga & 28 & $2,07 \pm 0,979$ & 0,024 \\
Teknik Distraksi & 28 & $1,50 \pm 0,638$ & \\
\hline
\end{tabular}

Dari tabel 8 diketahui bahwa pada penurunan dismenore nilai Asymp. Sig.(2tailed) pengujian Mann Whitney U pada uji beda skala dismenore antara kelompok kegiatan senam yoga dengan kelompok kegiatan teknik distraksi (mendengarkan musik klasik mozart) sebesar $0,024(<0,05)$ sehingga dapat dinyatakan pada penurunan dismenore terdapat perbedaan yang signifikan skala dismenore kelompok kegiatan senam yoga dengan kelompok kegiatan teknik distraksi (mendengarkan musik klasik mozart) pada Siswi SMA N 4 Pekalongan. Pada penurunan skala dismenore kelompok kegiatan yoga mempunyai nilai rata-rata skala dismenore sebesar 2,07 lebih besar daripada kelompok kegiatan teknik distraksi (mendengarkan musik klasik mozart) sebesar 1,50. Hal ini menunjukkan bahwa kelompok yoga lebih efektif dalam menurunkan skala dismenore daripada kelompok kegiatan teknik distraksi (mendengarkan musik klasik mozart).

\subsection{Senam Yoga dalam Menurunkan Nyeri Menstruasi (Dismenore)}

Dalam penelitian ini jenis senam yoga yang dipakai adalah jenis senam yoga dengan sikap kobra dan sikap kucing (cat pose). Sikap kobra ini sangat bermanfaat bagi tubuh wanita karena mengatur kelenjar anak ginjal (kelenjar suprarenal), memperkuat punggung, meningkatkan kelenturan tulang punggung, dan membantu menguatkan otot-otot perut. Selain itu juga meningkatkan energi dan kepercayaan diri. Senam ini juga membantu mengatur periode menstruasi dan meredakan ketegangan.

Sedangkan sikap kucing (cat pose) ideal bermanfaat untuk membantu meredakan nyeri perut selama masa sindrom premenstruasi, periode menstruasi, dan juga ideal untuk meredakan nyeri selama masa kehamilan. (Kanisius, 2009).

Dalam penelitian ini diketahui bahwa jumlah responden yang mengalami dismenore tingkat sedang pada saat pre test sebanyak 19 orang $(67,9 \%)$ dan responden yang mengalami dismenore tingkat ringan sebanyak 9 orang $(32,1 \%)$. Setelah dilakukan kegiatan senam yoga atau pada saat post test jumlah responden yang mengalami dismenore tingkat sedang menurun drastis menjadi 2 orang $(7,1 \%)$. Ini berarti terdapat 17 orang $(60,7 \%)$ yang mengalami penurunan dismenore dari tingkat sedang menjadi tingkat ringan. 
Hasil ini menunjukkan bahwa kegiatan senam yoga mempunyai pengaruh yang efektif dalam menurunkan dismenore, karena pada saat melakukan senam yoga siswi tersebut mengikuti senam yoga dengan serius, mengikuti kegiatan senam sampai selesai serta melakukan gerakan senam yoga sesuai apa yang diajarkan dengan sikap yoga yang diingkan, pada responden dengan intervensi senam yoga (di rumah) bisa menciptakan suasana yang tenang, rileks, aman maupun menyenangkan sehingga membuat suasana menjadi nyaman, bisa melakukan relaksasi yang mendalam.

Hal ini sejalan dengan penelitian yang dilakukan oleh (Nag U, Chakra arthy VK, Burra KC. 2013) dengan judul Efect Of Yoga On Progestone Levels And Pain Relief In Primary Dysmenorrhea. Penelitian ini menyimpulkan bahwa yoga dapat digunakan secara aman sebagai terapi alternatif menghilangkan rasa sakit dismenore.

Perbedaan dengan penelitian ini bahwasannya penulis juga membandingkan efektifitas senam yoga dengan teknik distraksi (mendengarkan musik klasik mozart) dalam rangka menurunkan dismenore.

Hasil penelitian ini sejalan dengan (Kusmiran, 2011) tentang cara-cara untuk mengatasi nyeri haid diantaranya adalah dengan latihan aerobik, seperti berjalan kaki, bersepeda, atau berenang, membantu memproduksi bahan alami yang dapat menghambat rasa sakit dan untuk melancarkan aliran darah pada otot sekitar rahim, sehingga rasa nyeri dapat teratasi atau berkurang, pakai kompres panas atau dingin pada daerah perut jika terasa nyeri, tidur yang cukup sebelum dan selama periode haid, dan latihan relaksasi atau yoga dapat membantu menanggulangi sakit.

Pendapat lain juga dikemukakan oleh Sindhu, P. (2009) Berlatih yoga secara teratur akan memberikan manfaat yang besar, antara lain: Meningkatkan fungsi kerja kelenjar endokrin (hormonal) di dalam tubuh. Meningkatkan sirkulasi darah ke seluruh sel tubuh dan otak. Membentuk postur tubuh yang lebih tegap, serta otot yang lebih lentur dan kuat. Meningkatkan kapasitas paru-paru saat bernapas. Membuang racun dari dalam tubuh (detoksifikasi).

Meremajakan sel-sel tubuh dan memperlambat penuaan. Memurnikan saraf pusat yang terdapat di tulang punggung. Mengurangi ketegangan tubuh, pikiran, dan mental, serta membuatnya lebih kuat saat menghadapi stres. Memberikan kesempatan untuk merasakan relaksasi yang mendalam. Meningkatkan kesadaran pada lingkungan. Meningkatkan rasa percaya diri dan kemampuan untuk berpikir positif.

\subsection{Teknik Distraksi (Mendengarkan Musik Klasik Mozart) Dalam Menurunkan Nyeri Menstruasi (Dismenore)}

Dalam penelitian ini diketahui bahwa jumlah responden yang mengalami dismenore tingkat sedang pada saat pre test sebanyak 17 orang $(60,7 \%)$ dan responden yang mengalami dismenore tingkat ringan sebanyak 11 orang (39,3\%). Setelah dilakukan kegiatan teknik distraksi (mendengarkan musik klasik mozart) atau pada saat post test jumlah responden yang mengalami dismenore tingkat sedang menurun menjadi 9 orang $(32,1 \%)$. Ini berarti terdapat 8 orang $(28,6 \%)$ yang mengalami penurunan dismenore dari tingkat sedang menjadi tingkat ringan.

Hasil ini menunjukkan bahwa kegiatan teknik distraksi (mendengarkan musik klasik mozart) mempunyai pengaruh yang efektif dalam menurunkan dismenore, namun untuk kenyamanan tempat sepertinya belum dikatakan nyaman karena tempat pada saat melakukan intervensi masih ada yang di sekolah dan di rumah, sehingga 
tingkat kenyamanan sepertinya terganggu, kurang nyaman, kurang rileks dan kurang tenang sehingga responden tidak bisa konsentrasi sepenuhnya saat melakukan teknik distraksi (mendengarkan musik klasik mozart), sehingga teknik distraksi (mendengarkan musik klasik mozart) tidak begitu efektif dalam menurunkan nyeri dismenore.

Teknik distraksi adalah salah satu cara untuk mengurangi nyeri dengan mengalihkan perhatian kepada sesuatu yang lain sehingga kesadaran klien terhadap nyerinya berkurang. Salah satu distraksi yang efektif adalah musik karena terbukti menunjukkan efek yaitu mengurangi kecemasan dan depresi, menghilangkan nyeri, menurunkan tekanan darah dan menurunkan frekuensi denyut jantung (Potter, (2002) dalam Sari, P. 2012). Musik yang dipilih pada umumnya musik lembut dan teratur, seperti instrumentalia atau musik klasik Mozart (Erfandi, 2009 \& Farida, (2010) dalam Sari, P. 2012).

Musik Klasik Mozart dapat merangsang peningkatan $\beta$ - endorfin yang disuplai oleh tubuh. Sehingga pada saat neuron nyeri perifer mengirimkan sinyal ke sinaps, terjadi sinapsis antara neuron perifer dan neuron yang menuju otak tempat seharusnya substansi $\mathrm{P}$ akan menghantarkan impuls. Pada saat tersebut, $\beta$ - endorfin akan memblokir lepasnya substansi $\mathrm{P}$ dari neuron sensorik sehingga transmisi impuls nyeri di medula spinalis menjadi terhambat dan sensasi nyeri berkurang (Farida, (2010) dalam Sari, P. 2012).

Pendapat-pendapat diatas juga telah membuktikan bahwa mendengarkan musik klasik mozart juga dapat menurunkan nyeri. Akan tetapi menurut Rasyid, F, (2010: 13) Musik adalah bunyi yang diterima oleh individu yang berbeda-beda berdasarkan sejarah, lokasi, budaya dan selera seseorang. Jadi hal ini akan mempengaruhi penurunan tingkat nyeri pada masing-masing responden yang menggunakan teknik distraksi (mendengarkan musik klasik mozart).

\subsection{Efektivitas senam Yoga dan Teknik Distraksi (Mendengarkan Musik Klasik Mozart) terhadap penurunan nyeri saat menstruasi (dismenore)}

Penurunan dismenore kelompok kegiatan senam yoga dengan kelompok kegiatan teknik distraksi (mendengarkan musik klasik mozart) sebesar 0,024 $(<0,05)$ sehingga dapat dinyatakan terdapat perbedaan penurunan dismenore kelompok kegiatan senam yoga dengan kelompok kegiatan teknik distraksi (mendengarkan musik klasik mozart) pada Siswi SMA N 4 Pekalongan. Sehingga dapat disimpulkan bahwa senam yoga mempunyai efektivitas yang lebih baik dalam menurunkan nyeri menstruasi (dismenore) daripada teknik distraksi (mendengarkan musik klasik mozart) yang dapat dilihat dari mean senam yoga sebesar $(2,07)$, sedangkan mean teknik distraksi (mendengarkan musik klasik mozart) sebesar $(1,50)$.

Hal tersebut juga diperkuat oleh pendapat Sindhu, P. (2009) yang mengatakan bahwa: Berlatih yoga secara teratur akan memberikan manfaat yang besar, antara lain: Meningkatkan fungsi kerja kelenjar endokrin (hormonal) di dalam tubuh. Meningkatkan sirkulasi darah ke seluruh sel tubuh dan otak. Membentuk postur tubuh yang lebih tegap, serta otot yang lebih lentur dan kuat. Meningkatkan kapasitas paruparu saat bernapas. Membuang racun dari dalam tubuh (detoksifikasi). Meremajakan sel-sel tubuh dan memperlambat penuaan. Memurnikan saraf pusat yang terdapat di tulang punggung. Mengurangi ketegangan tubuh, pikiran, dan mental, serta 
membuatnya lebih kuat saat menghadapi stres. Memberikan kesempatan untuk merasakan relaksasi yang mendalam. Meningkatkan kesdaran pada lingkungan. Meningkatkan rasa percaya diri dan kemampuan untuk berpikir positif. Sedangkan menurut pendapat Rasyid, F, (2010: 13) Musik adalah bunyi yang diterima oleh individu yang berbeda-beda berdasarkan sejarah, lokasi, budaya dan selera seseorang.

\section{KESIMPULAN}

Berdasarkan analisis data dan pembahasannya, maka dapat diambil kesimpulan sebagai berikut:

a) Terdapat perubahan skala nyeri sebelum dan sesudah senam yoga.

b) Terdapat perubahan skala nyeri sebelum dan sesudah teknik distraksi (mendengarkan musik klasik mozart).

c) Terjadi penurunan rata-rata skala nyeri sebelum dan sesudah senam yoga.

d) Terjadi penurunan rata-rata skala nyeri sebelum dan sesudah teknik distraksi (mendengarkan musik klasik mozart).

e) Terdapat perbedaan rata-rata nyeri sebelum dan sesudah senam yoga.

f) Terdapat perbedaan rata-rata nyeri sebelum dan sesudah teknik distraksi.

g) Terdapat perbedaan rata-rata nyeri antara yoga dan teknik distraksi (mendengarkan musik klasik mozart) dengan signifikasi $(p=0,024)$.

\section{SARAN}

\subsection{Bagi Responden}

Diharapkan responden khususnya remaja putri bisa menerapkan senam yoga dalam menanganani dismenore.

\subsection{Bagi Tenaga Kesahatan}

Bagi tenaga profesi keperawatan, diharapkan bisa berlatih senam yoga, sehingga bisa digunakan sebgai salah satu alternatif tindakan manajemen nyeri secara non farmakologi yang dapat dijadikan sebagai metode untuk menurunkan intensitas nyeri yang dapat diterapkan pada klien dengan dismenore.

\section{DAFTAR PUSTAKA}

Augustine, N. 2013. Effect Of Aerobic Exercises On Relief Of Dysmenorrhoea Among Adolescent Girls In Selected Rural Colleges Of Mulki, Mangalore, 11 - 12.

Grandiet all. 2012. Prevalence of menstrual pain in young women: what is dysmenorrhea? http://www.ncbi.nlm.nih.gov/pmc/articles/PMC3392715/

Kanisius. 2009. Bebas masalah kewanitaan. Yogyakarta: Kanisius (Anggota IKAPI)

Khoo, E ming. et all. 2010. Dysmenorrhea In A Multiethnic Population Of Adolescent Asian Girls. Volume 108 issue 2

Kusmiran, E. 2011. Kesehatan Reproduksi Remaja dan Wanita. Jakarta: Salemba Medika.

Marlinda, R. \& Rosalina. \& Purwaningsih, P; 2013. Pengaruh Senam Dismenore Terhadap Penurunan Dismenore Pada Remaja Putri Di Desa Sidoharjo Kecamatan Pati,1(2), 2.

Nag U, Chakravarthy V K, Burra KC. 2013. Effect Of Yoga On Progesterone Levels And Pain Relief In Primary Dysmenorrhea, 3 (2), 32.

Notoatmodjo, S. 2012. Metodologi Penelitian Kesehatan. Jakarta: Rineka Cipta 
Nursalam. 2008. Konsep Dan Penerapan Metodologi Penelitian Ilmu Keperawatan. Jakarta: Salemba Medika

Rasyid, F. 2010. Cerdaskan Anakmu Dengan Musik. Jogjakarta: Diva Press (Anggota IKAPI)

Sari, P. 2012. Perbedaan Terapi Musik Klasik Mozart Dengan Terapi Musik Kesukaan Terhadap Intensitas Nyeri Haid Pada Remaja Putri Di SMA Negeri 5 Denpasar

Siahaan, K. \& Ermiati. \& Maryati, I; 2012. Penurunan Tingkat Dismenore Pada Mahasiswi Fakultas Ilmu Keperawatan UNPAD Dengan Menggunakan Yoga

Sindhu, P. 2009. Hidup Sehat Dan Seimbang Dengan Yoga. Bandung: Qanita

Sumaryati, E. \& Hastomi, I. 2012. Terapi musik. Jogjakarta: javalitera 